\title{
Ekstrak Rosela Menurunkan Perlemakan dan Ekspresi ADMA Hepar akibat Diet Aterogenik pada Tikus
}

\section{Rosella's Extract Decrease Fatty Liver and ADMA Expression on Liver due to Atherogenic Diet in Mice}

\author{
Zuhrotun Ulya ${ }^{1}$, M Rasjad Indra' ${ }^{2}$ Supranowo ${ }^{3}$ \\ ${ }^{1}$ Program Studi Pendidikan Dokter Fakultas Kedokteran Universitas Brawijaya Malang \\ ${ }^{2}$ Laboratorium Ilmu Faal Fakultas Kedokteran Universitas Brawijaya Malang \\ ${ }^{3}$ Laboratorium Patologi Anatomi Fakultas Kedokteran Universitas Brawijaya Malang
}

\begin{abstract}
ABSTRAK
Rosela memiliki anthocyanin sebagai antioksidan polifenol yang berpotensi mencegah progresivitas penyakit akibat stres oksidasi. Diet aterogenik dan stres oksidasi memicu serangan radikal bebas pada komponen lemak dan protein sehingga terjadi perlemakan hepar dan peningkatan ekspresi ADMA (Asymmetric dimethylarginine). Penelitian ini bertujuan mengetahui pengaruh pemberian ekstrak rosela strain Hibiscus sabdariffa terhadap perlemakan hepar dan ekspresi ADMA hepar pada tikus Rattus norvegicus yang diberi diet aterogenik. Studi eksperimental menggunakan post test only control group pada Rattus norvegicus strain Wistar jantan yang dibagi dalam empat kelompok, yaitu kelompok kontrol positif (diet aterogenik), kelompok1 (ekstrak rosela 150mg/kgBB/hari + diet aterogenik), kelompok 2 (ekstrak rosela $300 \mathrm{mg} / \mathrm{kgBB} / \mathrm{hari}+$ diet aterogenik), dan kelompok kontrol negatif (tanpa pemberian diet aterogenik dan ekstrak rosela). Hasil penelitian menunjukkan bahwa ekstrak rosela mampu menurunkan perlemakan hepar yang berdasar pemeriksaan histopatologi berupa jumlah sel yang mengalami perlemakan lebih sedikit $(p=0,000)$. Ekspresi ADMA dari gambaran imunohistokimia menunjukkan ekspresi yang lebih sedikit pada kelompok dengan diberi ekstrak rosela $(p=0,000)$. Dapat disimpulkan pemberian ekstrak rosela menghambat perlemakan hepar akibat diet aterogenik dan ekspresi ADMA akibat diet aterogenik pada tikus, dengan dosis optimum rosela $300 \mathrm{mg} / \mathrm{kgBB} / \mathrm{hari}$.
\end{abstract}

Kata Kunci: Diet aterogenik, ekspresi ADMA hepar, perlemakan hepar, rosela

\begin{abstract}
Anthocyanin in rosella, as polyphenol antioxidant, has a potential impact to prevent the progressivity of disease related to oxidative stress. Atherogenic diet and oxidative stress will induce free radical attack on fat and protein compound resulting in fatty liver and increasing ADMA (asymmetric dimethylarginine) expression increase. This study aimed to investigate antioxidant effect of rosella's extract in fatty liver and ADMA expression of Rat with atherogenic diet. Experimental study with post test only control group was conducted using four randomized experimental groups which were: positive control group (atherogenic diet), group 1 (rosella's extract 150mg/kgBW/day + atherogenic diet), group 2 (rosella's extract $300 \mathrm{mg} / \mathrm{kgBW} / \mathrm{day}+$ atherogenic diet), and negative control group without intervention. Our findings revealed that rosella's extract has potential impact in reducing fatty liver as expressed in significant reducing of fatty cells $(p=0,000)$. Based on immunohistochemistry examination, rosella extract consumption will decrease ADMA expression $(p=0,000)$. It can be concluded that rosella extract consumption at dosage $300 \mathrm{mg} / \mathrm{kgBW} /$ day has significant impact in reducing fatty liver and ADMA expression due to atherogenic diet in Rat.
\end{abstract}

Keywords: ADMA expression on liver, atherogenic diet, fatty liver, rosella

Jurnal Kedokteran Brawijaya, Vol. 28, No. 1. Februari 2014; Korespondensi: Zuhrotun Ulya. Program Studi Pendidikan Dokter Fakultas Kedokteran Universitas Brawijaya Malang, Jl. Veteran Malang Tel. (0341) 566117Email: dr.zulya@ub.ac.id 


\section{PENDAHULUAN}

Penelitian oleh Chang di Jepang dan Hirunpanich di Amerika pada tahun 2006 membuktikan secara in vitro potensi Hibiscus anthocyanin yang mampu menghambat Low Density Lipoprotei (LDL) teroksidasi untuk menginduksi apoptosis pada makrofag melalui penghambatan fragmentasi apolipoprotein B. Rosela strain Hibiscus sabdariffa yang mengandung antioksidan anthocyanin, mulai dimanfaatkan sebagai bahan penelitian dengan kerangka pemikiran bahwa potensi antioksidan dalam rosela dapat bekerja sebagai agen penghambat efek stres oksidatif (1).

Diet aterogenik dapat menimbulkan kondisi hyperlipidemia, yang menyebabkan terbentuknya radical oxygen species (ROS) sehingga menimbulkan reaksi berantai berupa pembentukan LDL teroksidasi yang akan ditangkap makrofag melalui reseptor scavenger yang pada akhirnya terakumulasi menjadi sel busa dan garis lemak di pembuluh darah. ROS bereaksi cepat dan mendenaturasi protein, lipid, asam nukleat, karbohidrat dan molekul lain yang mengakibatkan inflamasi, apoptosis, fibrosis dan proliferasi sel (2).

Asymmetric diimethylarginine (ADMA) merupakan sejenis inhibitor endogen dari eNOS yang kadarnya dapat meningkat pada kondisi stres oksidatif seperti atherosclerosis, obesitas, penyakit hepar, hipertensi, stres oksidatif yang akan mengaktivasi PRMTs sehingga terjadi proteolysis l-arginine yang berperan dalam pelepasan ADMA. ADMA akan difiltrasi oleh glomerulus dan diserap kembali oleh sel tubuli. Dalam tubuh manusia dalam kondisi normal ADMA secara selektif didegradasi dan terdistribusi di ginjal, hepar dan usus kecil. Pada kondisi patologis, kadar ADMA meningkat di jaringan sehingga ADMA bisa dijadikan marker penyakit seperti kondisi perlemakan hepar $(3,4)$.

Diet aterogenik akan memicu kondisi hyperlipidemia dan diikuti perlemakan hepar. Semakin lama tubuh mengalami hyperlipidemia maka mudah diikuti kondisi stres oksidatif sehingga kadar antioksidan dalam tubuh berkurang. Dalam kondisi tersebut LDL teroksidasi akan meningkat dan terjadi peningkatan kadar ADMA (5). Dengan adanya antioksidan anthocyanin diharapkan dapat memperbaiki kondisi akibat stres oksidatif dan mencegah rangkaian kondisi patologis akibat diet aterogenik. Penelitian ini dilakukan untuk membuktikan efek anthocyanin pada bunga rosela terhadap perlemakan hepar dan ekspresi ADMA hepar pada tikus Rattus norvegicus yang diberi diet aterogenik.

\section{METODE}

Penelitian ini merupakan penelitian eksperimental menggunakan hewan coba tikus dengan metode randomized completely design. Subjek penelitian menggunakan tikus Rattus norvegicus strain Wistar jantan, umur 2 bulan dengan rata-rata berat badan 130 150 gram, sejumlah 5 tikus dalam 1 kelompok uji sehingga dibutuhkan 20 ekor tikus untuk 4 kelompok.

Intervensi yang dilakukan adalah pemberian ekstrak rosela $150 \mathrm{mg} / \mathrm{kgBB}$ sekali sehari, ekstrak rosela $300 \mathrm{mg} / \mathrm{kgBB}$ sekali sehari dan pemberian diet aterogenik setiap hari selama 2 bulan. Pemberian diet aterogenik pada kelompok kontrol positif (hanya diberikan diet aterogenik saja), kelompok I (yang diberi diet aterogenik dan ekstrak rosela150mg/kgBB/hari), dan kelompok II (yang diberi diet aterogenik dan ekstrak rosela $300 \mathrm{mg} / \mathrm{kgBB} /$ hari). Efek yang diamati adalah ekspresi ADMA pada hepar dan perlemakan hepar pada tikus. Variabel kontrol terdiri dari jenis tikus, umur, jenis kelamin, berat badan awal, dosis dan waktu pemberian ekstrak rosela, pemberian pakan aterogenik, kondisi lingkungan kandang, serta komposisi ekstrak rosela yang telah distandarisasi.

Bahan yang digunakan adalah tikus Rattus norvegicus strain Wistar jantan, ekstrak rosela yang telah distandarisasi, pakan standar dan pakan aterogenik, dan bahan untuk pemeriksaan laboratorium. Instrumen penelitian menggunakan gelas ekstraksi, neraca analitik, bak penampung air dingin, alat ekstraksi metode frezz drying, batu kapur, kandang tikus, pakan aterogenik, sonde lambung, alat bedah, alat pemeriksaan laboratorium, serta alat persiapan preparat slide jaringan hepar dengan metode vriescope dan imunohistokimia.

Pada awal perlakuan tikus menjalani masa adaptasi selama 1 minggu, kemudian selama 60 hari diberikan perlakuan inti yaitu pemberian diet aterogenik dan ekstrak teh merah dalam kelompok I (ekstrak rosela dosis $150 \mathrm{mg} / \mathrm{kgBB}$ ) dan II (ekstrak rosela dosis $300 \mathrm{mg} / \mathrm{kgBB}$ ), pemberian diet aterogenik untuk kelompok kontrol positif (KP) dan pakan standar untuk kelompok kontrol negatif (KN). Pembedahan dilakukan setelah perlakuan selama 60 hari, untuk mendapatkan hepar tikus. Dilakukan pemeriksaan perlemakan hepar dan teknik imunohistokimia untuk menilai ekspresi ADMA hepar tikus.

Pengamatan preparat dilakukan dibawah mikroskop dengan perbesaran 400x untuk menilai jumlah sel hepar yang mengalami perlemakan dan menilai ekspresi ADMA hepar. Data perlemakan dan ekspresi ADMA hepar diolah dan dianalisis melalui uji homogenitas variances, one way ANOVA, post hoc test, dan uji korelasi.

\section{HASIL}

Hasil pemeriksaan histopatologi perlemakan hepar, pada pengamatan di bawah mikroskop perbesaran 400x disajikan pada Gambar 1.

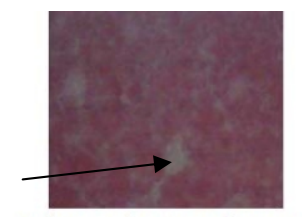

Kelompok Kontrol Positif

Kelompok Teh merah 150mg/kgBB
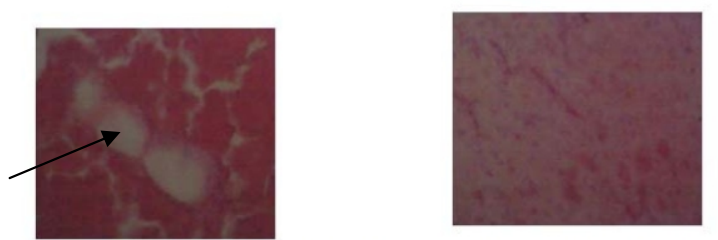

Kelompok Teh merah 300 mg/kgBB Kelompok Kontrol Negatif

Gambar 1. Hasil Pemeriksaan histopatologi perlemakan hepar (perbesaran 400x)

Keterangan: Tanda panah menunjukkan sel hepar yang mengalami perlemakan

Pada kelompok kontrol positif yang diberi diet aterogenik 
tanpa ekstrak rosela, tampak seluruh sel hepar mengalami perlemakan, sinusoid tidak nampak dengan sel berbentuk tidak beraturan. Rata-rata jumlah sel hepar yang mengalami perlemakan persepuluh lapang pandang sebesar 83,72. Pada kelompok yang diberi diet aterogenik dan ekstrak rosela dosis $150 \mathrm{mg} / \mathrm{kgBB} /$ hari nampak perlemakan hepar yang lebih sedikit dibandingkan kelompok kontrol positif, dengan rata-rata jumlah sel hepar yang mengalami perlemakan persepuluh lapang pandang 37,86. Pada kelompok yang diberi diet aterogenik dan ekstrak rosela dosis $300 \mathrm{mg} / \mathrm{kgBB} / \mathrm{hari}$ perlemakan hepar lebih sedikit dengan beberapa sel hepar berbentuk kubus dan susunan sel hati lebih teratur dengan ukuran dan bentuk lebih homogen dengan ratarata jumlah sel hepar yang mengalami perlemakan persepuluh lapang pandang 15,86. Pada kelompok kontrol negatif tanpa diet aterogenik dan tanpa ekstrak rosela, sebagian besar menunjukkan kondisi sel hepar yang normal dengan bentuk kubus tersusun radial dan sinusoid diantara sel hepar dengan jumlah sel hepar yang mengalami perlemakan persepuluh lapang pandang 2,4.

Hasil uji one way ANOVA menunjukkan perbedaan bermakna jumlah perlemakan hepar pada kelompok perlakuan $(p=0,000)$. Hasil analisis post hoc menunjukkan hasil tes $p<0,05$ pada kelompok KP dibanding dosis $150, \mathrm{KP}$ dibanding dosis 300, KP dibanding $\mathrm{KN}$, dosis 150 dibanding dosis 300 , dosis 150 dibanding $\mathrm{KN}$, dan dosis 300 dibanding KN. Dengan demikian terdapat perbedaan jumlah perlemakan hepar yang bermakna. Dapat disimpulkan bahwa kondisi perlemakan hepar pada tikus dengan diet aterogenik dan ditambah ekstrak rosela lebih rendah dibandingkan tikus dengan diet aterogenik saja.

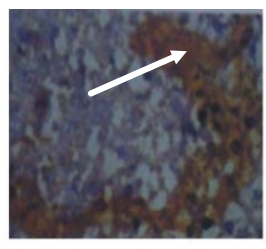

Kelompok Kontrol Positif

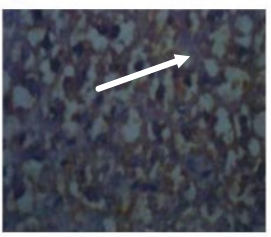

Kelompok Teh merah 300 mg/kgBB

$B$

Kelompok Kontrol Negatif
Gambar 2. Hasil pemeriksaan imunohistokimia ADMA hepar (perbesaran 400x)

Keterangan: Tanda panah menunjukkan ekspresi ADMA hepar

Hasil pemeriksaan imunohistokimia ADMA hepar dibawah mikroskop dengan perbesaran 400x pada Gambar 2 menunjukkan bahwa pada kelompok kontrol positif, sebagian besar tampak ADMA hepar pada permukaan sel hepar dan sinusoid dengan ekspresi ADMA yang relatif luas. Rata-rata jumlah sel hepar yang disertai ekspresi ADMA persepuluh lapang pandang sebesar 25,20 . Pada kelompok yang diberi diet aterogenik dan ekstrak rosela dosis $150 \mathrm{mg} / \mathrm{kgBB} /$ hari tampak ekspresi ADMA hepar seperti kelompok kontrol positif namun lebih sedikit dengan rata-rata jumlah sel hepar yang disertai ekspresi ADMA persepuluh lapang pandang 16,56. Pada kelompok yang diberi diet aterogenik dan ekstrak rosela dosis $300 \mathrm{mg} / \mathrm{kgBB} /$ hari ekspresi ADMA jauh lebih sedikit dengan rata-rata jumlah sel hepar yang disertai ekspresi ADMA persepuluh lapang pandang 7,72. Pada kelompok kontrol negatif tanpa diet aterogenik dan tanpa ekstrak rosela, didapatkan sedikit ekspresi ADMA yang hanya muncul di permukaan sel hepar dan lebih banyak bentukan sel hepar yang tidak disertai ekspresi ADMA.

Hasil uji one way ANOVA menunjukkan terdapat perbedaan bermakna $(p=0,000)$ jumlah ekspresi ADMA hepar pada kelompok perlakuan. Hasil analisis post hoc menunjukkan perbedaan bermakna pada kelompok kontrol positif dibandingkan dengan kelompok I, kelompok II, dan kontrol negatif. Kelompok I dibandingkan dengan kelompok II dan kontrol negatif, dan kelompok II dibanding kontrol negatif. Dapat disimpulkan bahwa ekspresi ADMA hepar pada tikus dengan diet aterogenik dan ekstrak rosela lebih rendah dibandingkan tikus dengan diet aterogenik saja.

Pada uji korelasi Pearson didapatkan nilai p-value 0,000 dengan koefisien korelasi 0,982 yang menunjukkan terdapat hubungan positif kuat yang bermakna antara perlakuan (pemberian eksrak rosela) dengan perlemakan hepar dan ekspresi ADMA hepar pada semua kelompok. Semakin tinggi jumlah perlemakan hepar diikuti peningkatan ekspresi ADMA hepar. Pemberian ekstrak rosela dapat menurunkan jumlah perlemakan hepar dan ekspresi ADMA. Ekspresi ADMA hepar pada pemberian rosela dosis $300 \mathrm{mg} / \mathrm{kgBB}$ dan kontrol negatif tidak berbeda bermakna yang menunjukkan pada dosis tersebut mampu memperbaiki ekspresi ADMA hingga sama dengan normal.

\section{DISKUSI}

Anthocyanin dalam rosela merupakan senyawa antioksidan golongan polifenol yang telah dibuktikan mampu menghambat produksi LDL teroksidasi, memiliki efek hipolipidemik dan menghambat terjadinya atherosclerosis $(1,6)$. Konsumsi diet aterogenik dalam jangka waktu lama akan menyebabkan peningkatan saturation fatty acid sehingga tubuh mengalami hyperlipidemia sehingga mampu meningkatkan kejadian penyakit jantung, plak pembuluh darah, dan perlemakan hepar $(7,8)$. Adanya biomarker tubuh dapat berguna untuk evaluasi koreksi dan terapi pada kondisi perlemakan hepar. Dalam tubuh manusia didapatkan protein homolog asam amino arginin yang jumlahnya meningkat apabila tubuh dalam kondisi patologis. Protein tersebut adalah ADMA, yang dalam kondisi normal secara selektif didegradasi dan terdistribusi di ginjal, hepar dan usus kecil. Kadar ADMA meningkat pada kondisi obesitas, hyperlipidemia, peningkatan stres oksidatif dan kondisi patologis seperti gagal ginjal, gagal jantung, atherosclerosis dan perlemakan hepar. Diet aterogenik menyebabkan peningkatan kejadian perlemakan hepar dan ekspresi ADMA hepar $(9,10)$.

Diet aterogenik menjadi penyebab perlemakan hepar karena memiliki komposisi tinggi lemak sehingga menyebabkan tubuh mengalami peningkatan kadar asam lemak bebas dalam plasma yang terjadi akibat mobiisasi lemak dari jaringan adipose atau dari hasil hidrolisis lipoprotein lipase dalam jaringan ekstra hepatik akan 
diambil oleh hati dan mengalami esterifikasi (11). Saat terjadi gangguan keseimbangan antara sintesis trigliserida dan VLDL yang tidak dapat mengikuti kecepatan aliran masuk asam lemak bebas menyebabkan penimbunan trigliserol di hepar. Asam lemak bebas yang diambil dan disintesis oleh hati lebih banyak yang tidak mengalami oksidasi di mitokondria tapi diesterifikasi menjadi trigliserid yang terakumulasi dalam sitoplasma (12). Peran dari stres oksidatif diakibatkan oleh penimbunan asam lemak intrahepatik. Timbulnya radikal bebas yang meningkat dan mempengaruhi peroksidasi lipid sehingga berpotensi menyebabkan kerusakan lipid dan menimbulkan berbagai gangguan fungsi dan integritas sel hati

Saat proses stres oksidatif berjalan, terjadi serangan radikal bebas pada komponen tubuh seperti lemak dan protein. Jika mengenai komponen lemak maka memicu produksi LDL-teroksidasi dan berefek pada peningkatan ADMA. Stres oksidatif menstimulasi PRMTs yang kemudian terjadilah proteolisis I-arginine sehingga terbentuk ADMA. Semakin tinggi tingkat stres oksidatif pada komponen lemak dan protein dapat meningkatkan kadar ADMA (9).

Pemberian ekstrak rosela konsentrasi $150 \mathrm{mg} / \mathrm{kgBB} /$ hari mampu menurunkan jumlah perlemakan hepar dan ekspresi ADMA. Hal ini bisa terjadi karena anthocyanin dalam rosela sebagai antioksidan primer bekerja dengan memotong rantai stres oksidatif dikarenakan memiliki ikatan rangkap dan gugus hidroksil pada senyawa polifenol sehingga menimbulkan aksi pengikatan radikal bebas dan menghambat terjadinya oksidasi LDL. Anthocyanin akan menghalangi reaksi oksidasi pada tahap inisiasi maupun propagasi, sehingga senyawa radikal yang terbentuk tidak punya cukup energi untuk dapat bereaksi dengan molekul lipid lain untuk membentuk radikal lipid baru.

Pada pemberian ekstrak rosela konsentrasi $300 \mathrm{mg} / \mathrm{kgBB} /$ hari menunjukkan efek yang lebih baik dalam menurunkan jumlah perlemakan hepar dan ekspresi ADMA hepar dibandingkan konsentrasi $150 \mathrm{mg} / \mathrm{kgBB} / \mathrm{hari}$. Dengan penambahan dosis konsentrasi ekstrak rosela menunjukkan kemampuan antioksidan yang lebih baik dalam menghalangi reaksi oksidatif, dan dosis $300 \mathrm{mg} / \mathrm{kgBB} /$ hari masih efektif dalam

\section{DAFTAR PUSTAKA}

1. Chang YC, Huang KX, Huang AC, and Wang CJ. Hibiscus Anthocyanins-Rich Extract Inhibited LDL Oxidation and ox-LDL Mediated Macrophages Apoptosis. Food and Chemical Toxicology. 2006; 44(7): 1015-1023.

2. Prijadi B. Pengaruh Pasta Tomat terhadap Jumlah Sel Busa Aorta Tikus dengan Diet Aterogenik. Jurnal Kedokeran Brawijaya. 2007; 5: 92-99.

3. Leone A, Vallance P, Calver A, Collier J, and Moncada S. Endogenous Dimethylarginine as an Inhibitor of Nitric Oxide Synthesis. Journal of Cardiovascular Pharmacology. 1992; 20: 60-62.

4. Sydow K, Schwedheim E, Arakawa N, et al. ADMA and Oxidative Stress are Responsible for Endothelial Dysfunction in Hyperhomocsyteinemia, Effects of LArginine and $B$ vitamins. Journal of Cardiovascular Research. 2003; 57: 244-252. menurunkan jumlah perlemakan hepar dan ekspresi ADMA hepar.

Hasil penelitian yang telah dikemukakan, dimungkinkan hanya berlaku khusus pada organ hepar dengan kondisi perlemakan hepar disertai peningkatan ekspresi ADMA hepar. Hasil akan berbeda jika penelitian menggunakan parameter berbeda seperti pengukutan terhadap SOD, TNF- $\alpha$, kolesterol, atau ekspresi ADMA pada organ lain seperti ginjal, usus kecil dan darah, karena kepekaan atau respon berbagai organ tubuh akan berbeda terhadap cara kerja, jumlah dosis yang diberikan dan mekanisme kerja subseluler dari antioksidan.

Hepar akan mudah mengenali antioksidan yang masuk dalam tubuh, hal ini dimungkinkan karena ekstrak antioksidan yang masuk melalui saluran pencernaan akan mengalami uptake dari usus ke hepar dan masuk dalam sirkulasi hepar. Saat masuk dalam sirkulasi hepar tersebut, antioksidan mulai bekerja melawan radikal bebas yang sedang atau sudah menyerang komponen lemak dalam sel hepar $(13,14)$. Selain itu, terbaginya hepar dalam 3 zona akan mempermudah kerja antioksidan, karena sejak zona I antioksidan akan mempengaruhi komponen sel dan berlanjut hingga zona III di hepar. Mekanisme dan hasil yang berbeda dimungkinkan akan terjadi pada ekspresi ADMA di serum, karena peningkatan ADMA serum bersifat sesaat dan mudah hilang dengan mekanisme yang masih belum diketahui $(15,16)$.

Penambahan antioksidan primer dengan konsentrasi rendah dapat menghambat atau mencegah reaksi oksidasi komponen lemak pada tahap inisiasi maupun propagasi. Dengan demikian besar konsentrasi antioksidan yang ditambahkan dapat berpengaruh pada laju oksidasi. Pada konsentrasi tinggi, aktivitas antioksidan grup polifenol sering lenyap bahkan antioksidan sering menjadi prooksidan $(17,18)$. Dari hasil yang ada pemberian dosis $300 \mathrm{mg} / \mathrm{kgBB} /$ hari masih efektif untuk menurunkan jumlah perlemakan hepar dan ekspresi ADMA hepar.

Hasil penelitian ini membuktikan bahwa pemberian ekstrak rosela mampu menurunkan jumlah perlemakan hepar dan ekspresi ADMA hepar pada tikus Rattus Norvegicus yang diberi diet aterogenik. Dosis $300 \mathrm{mg} / \mathrm{kg} / \mathrm{BB} /$ hari terbukti sebagai dosis yang lebih baik dibandingkan dosis $150 \mathrm{mg} / \mathrm{kgBB} /$ hari dan memberikan gambaran perbaikan sama dengan kondisi normal.

5. Mayes, PA. Transportation and Storage of Lipid. Di dalam: Murray RK, Granner DK, and Rodwell VW (Ed). Harper'sBiochemistry edisi 25. Jakarta: Penerbit Buku Kedokteran EGC; 2003: hal. 254-269.

6. Hirunpanich V, Anocha U, Noppawan PM, et al. Hypocholesterolemic and Antioxidant Effect of Aqueos Extract from the Dried Calyx of Hibiscus sabdariffa L. in Hypercholesterolemic Rats. Journal of Etnopharmacology. 2006; 103(2): 252-260.

7. Murwani S, Ali M, Muliartha K. Diet Aterogenik pada Tikus Putih (Rattus Norvegicus Wistar) sebagai Model Hewan Ateroskleoris. Jurnal Kedokteran Brawijaya. 2006; 22: 6-9.

8. Tjokroprawiro A. Globesity the Time-Bomb Disease in the Future? Capita Selecta in Endocrinology. Prosiding Seminar the $22^{\text {nd }} \mathrm{CME}$ of Internal Medicine. Surabaya, 11-12 Agustus 2007; hal. 2-10. 
9. Vallance P, Leone A, Calver A, Collier J, and Moncada S. Accumulation of an Endogenous Inhibitor of Nitric Oxide Synthesis in Chronic Renal Failure. The Lancet. 1992; 339: 572-575.

10. Nijveldt RJ, Teerlink T, Siroen MP, et al. Asymmetrical DImethylarginine (ADMA) in Criticallay III Patients: High Plasma ADMA concentration is an Independent Risk Factor of ICU Mortality. Clinical Nutrition. 2003; 22(1): 23-30.

11. Surdacki A, Nowicki M, Sandmann J, et al. Reduced Urinary Excretion of Nitric Oxide and Increased Plasma Levels of Asymmetrical Dimethylarginine in Men with Essential Hypertension. Journal of Cardiovascular Pharmacology. 2004; 33: 652-658.

12. Soemarto WD. Perlemakan Hati. Di dalam: Buku Ajar Ilmu Penyakit Dalam. Jakarta: Balai Penerbit FKUI; 1996: hal. 333-335.

13. Dullo AG, Antic V, Montani JP. Preface Pathogenesis of the Worst Killer of the $21^{\text {st }}$ Century. International Journal of Obesity. 2002; 26: 1-2
14. Cantarow A and Trumper M. Clinical Biochemistry.9th edition. Philadelphia: WB Saunders Company; 2000; hal. 143-151.

15. Nijveldt RJ, Teerlink T, Siroen MP, et al. The Liver is an Important Organ in the Metabolism of Asymmetrical Dlmethylarginine (ADMA). Clinical Nutrition Journal. 2003; 22(1): 17-22.

16. Usui M, Matsuoka H, Miyazaki H, Ueda S, Okuda S, and Imaizumi T. Increased Endogenous Nitric Oxide Synthase Inhibitor in Patients with Congestive Heart Failure. Life Science Journal. 1998; 62(26): 2425-2430.

17. Xiong Y, Fu YF, Fu Sh, and Zhou HH. Elevated Levels of the Serum Endogenous Inhibitor of Nitric Oxide Synthase and Metabolic Control in Rats with Streptozotocin-induced Diabetes. Journal of Cardiovascular Pharmacology. 2003; 42(2): 191-196.

18. Vaziri ND. Roles of Oxidative Stress and Antioxidant Therapy inChronic Kidney Disease and Hypertension. Current Opinion in Nephrology and Hypertension. 2004; 13(1): 93-99. 